\title{
Evolutionary genetics and morphometrics of a cave crayfish population from Chiapas (Mexico)
}

\author{
Valerio Sbordoni *, Giuliana Allegrucci ,* \\ Fabiola Baldari * and Donatella Cesaroni *
}

SUMMARY

The recently explored Cueva de Los Camarones, in the remote village of Constitucion, Chiapas, Mexico, houses a unique highly variable population of Procambarus crayfish (Crustacea, Decapoda). Morphologically, a more or less clinal variation is revealed at several features such as the degree of rudimentation in both pigmentation and eye, and the elongation of body and appendages. Extremes are quite different, ranging from typical dark, thick, eyed individuals to light, elongated, microphtalmic phenotypes. Evolutionary relationships among individuals were investigated electrophoretically (25 structural gene loci) and morphometrically (12 characters) by means of multivariate analyses. Results from analysis of individual allozymic multilocus profiles indicate that the "light " phenotypes belong to a distinct gene pool with respect to the "dark" ones, but some level of introgression is hypothesized. Results from analysis of individual morphometric profiles also show a discrimination between "light * and * dark " samples, chiefly determined by the shape of the rostrum and chela. The existence of such a discontinuous variation both in morphometric and allozymic characters presumably reflects a history of allopatric divergence followed by secondary contact of the two species.

Following earlier biospeleological investigations in Mexico supported by the Accademia Nazionale dei Lincei (Sbordoni and Argano, 1972; Sbordoni et al., 1973, 1977; Reddell, 1981), the most recent Italian expeditions called "Malpaso " were carried out in the southern state of Chiapas and produced a deal of speleological and biospeleological discoveries (Circolo Speleologico Romano, 1986).

* Department of Biology, 2nd University of Roma * Tor Vergata *, Italy via Orazio Raimondo, I - 00173 ROMA Italy. 
Besides several taxonomic novelties, the "Malpaso" expeditions led to discover a few aquatic cave populations which appear to be of special interest for the evolutionary biologist. These include Rhamdia Pimelodid fish, Pseudothelphusid crabs, undetermined snails as well as Procambarus crayfish (Sbordoni et al., 1986). Basically these populations show a deal of individual variability in several troglomorphic features at such an extent that extreme epigean-like vs troglobite-like forms could appear to belong to distinct species.

Had a palaeontologist found a similar situation in the fossil records, he could interpret these contrasting morphologies as instances of punctuation. Thus, among several good reasons to investigate these phenomena, one is to elucidate the "tempo and mode" of their evolution.

This paper reports preliminary analyses carried out on an unique, highly variable population of Procambarus crayfish, disccvered during "Malpaso '84 " expedition. This population inhabits a recently explored cave, Cueva de Los Camarones, in the remote village of Constitucion, $30 \mathrm{~km}$ North of Cintalapa, Chiapas. The cave, described by Gambari and Topani (1986), consists of two main passages, one of which is traversed by a periennal stream. Near the entrance a lake-siphon occurs, providing water to the surface river. The cave stream is about $1 \mathrm{~km}$ long, and terminates in another siphon. Procambarus crayfishes were widespread throughout the stream, beginning from the lake near the entrance up to the inner explored section of the cave. Morphologically, a more or less clinal variation is revealed at several features such as the degree of rudimentation in both pigmentation and eye, and the elongation of body and appendages (Fig. 1). Extremes are quite different, ranging from typical dark, thick, eyed, surface-like individuals to light, elongated, microphtalmic, troglobite-like phenotypes (Sbordoni et al., 1986).

Studies concerning analogous situations, also in other organisms, are not very numerous, although some of them reported in the literature are well known (for a review see Culver, 1982). Very high within population variation in cavernicolous traits has been usually interpreted as due to hybridization with a surface ancestor still alive, after relatively short periods of isolation in caves.

The characin fish Astyanax fasciatus, one of the most common freshwater fishes in Middle America, represents the best known case of populations with adaptive characters for cave environment that can still interbreed with surface populations. This species has developed a series of cave living populations isolated from surface ones for periods of time as a result of subterranean stream capture, within a geographically limited area in Central 
Mexico (Mitchell et al., 1977). Part of cave living populations, which were originally described as species, are characterized by the almost complete reduction of eyes and pigmentation. Two further populations show variability of eye and pigmentation. In particular, the Chica cave contains a hybrid population between an extremely reduced cave form and the epigean population (Avise and Selander, 1972; Wilkens, 1972, 1985). The Chica cave situation appears to be comparable, at least morphologically, to that found in Procambarus crayfish in the Cueva de Los Camarones, although underlying evolutionary processes $\mathrm{mi}-$ ght not be the same.

A first sampling of Procambarus population in the Cueva de Los Camarones was made in 1986, keeping apart individuals collected in the lake from those in the inner section of the cave stream. Typical «light» phenotypes were collected only in this portion of the cave, although at least one individual was observed in the lake. In order to enlighten evolutionary relationships among individuals, it has been investigated on possible quantitative and qualitative differences between the two extremes " light " and "dark" phenotypes, at the morphological and allozymic level.

\section{MATERIAL AND METHODS}

Unfortunately, out of 37 individuals only 18 arrived still alive in the laboratory and were utilized also for electrophoretic analysis; other 19 specimens were preserved in alcohol and were utilized only for morphometrical analysis. The crayfishes were subdivided in two groups: 16 light individuals, all males, 13 of which alive, and 21 dark individuals, 8 males and 13 females, only 5 of which alive. The "dark " group includes samples more or less darkly pigmented.

Each individual was assayed at 25 enzyme loci by horizontal starch gel electrophoresis, using crude homogenates of abdominal muscle or of the cephalotorax, depending on the enzymes. The enzyme patterns were revealed according to the procedures described in Ayala et al. (1972) and Harris and Hopkinson (1976). The following enzymes were assayed: alkaline phosphatase $(\mathrm{Aph})$, aldehyde oxidase ( $\mathrm{Ao})$, carbonic anhydrase $(\mathrm{Ca})$, fumarase (Fum), glutamate oxaloacetate transaminase (Got), isocitrate dehydrogenase $(I d h)$, leucine aminopeptidase $(L a p)$, lactate dehydrogenase $(L d h)$, malic enzyme $(M e)$, malate dehydrogenase $(M d h)$, mannose phosphate isomerase (Mpi), peptidase 


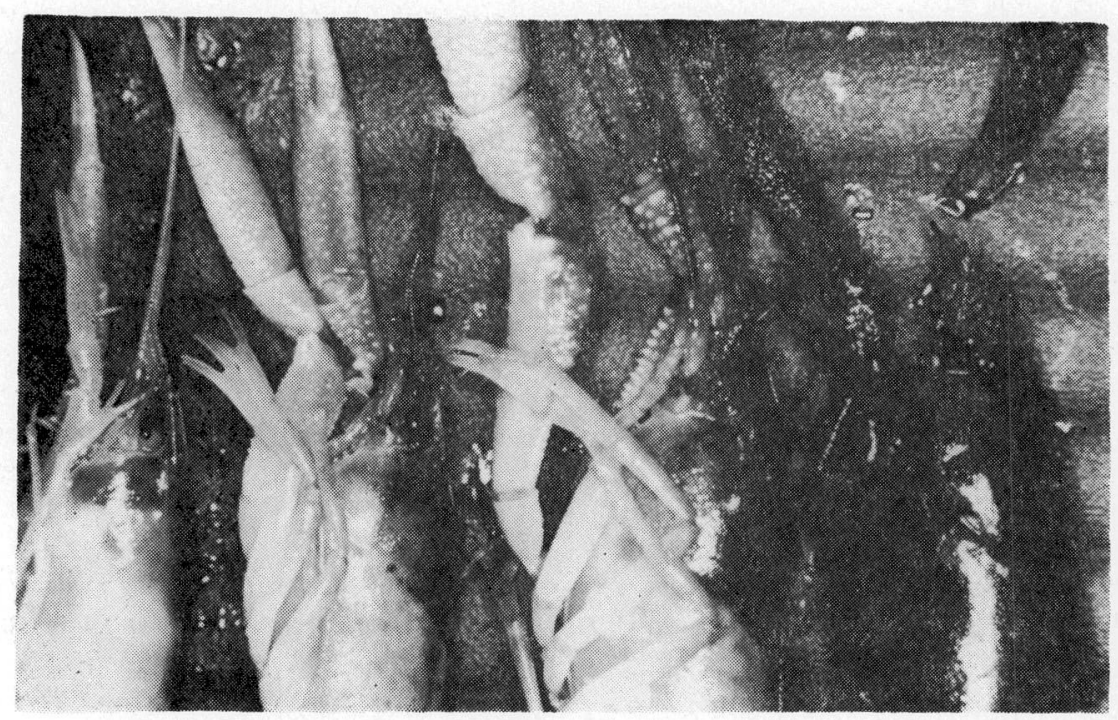

Fig. 1 - Four Procambarus specimens from the Cueva de Los Camarones. Lack of pigmentation, thickness of appendages and eye reduction are visible in the "light" phenotype (on the left) with respect to the extreme "dark" one (on the right). Individuals in between show intermediate characters.

$(P e p)$, phosphoglucomutase $(P g m)$, phosphoexose isomerase $(P h i)$, xanthine dehydrogenase $(X d h)$, superoxide dismutase $(S o d)$ and some other non-enzymatic proteins $(P t)$.

F-statistics analysis $\left(\mathrm{F}_{\mathrm{st}}\right.$; Wright, 1965$)$ was utilized to measure differentiation between the two groups. Significance of the observed $F_{\text {st }}$ values per locus was tested with a chi-square heterogeneity test (Workman and Niswander, 1970). Estimates of genetic identity (I) and distance (D) between dark and light crayfishes were calculated using Nei's method (1972).

Biometric analysis was made on a sample of 29 individuals, including only 10 out of those assayed electrophoretically, because of heavy damages of the 8 remaining animals. Each specimen has been measured for 12 different characters using uniform techniques; carapace length (CAL), rostrum length and width (ROL and ROW), dactyl length (CDL), palm length and width (CPL and CPW), length of mesial margin of palm (CML), carpus length (CCL), merus length (MEL), abdomen length (ABL), telson length and width (TEL and TEW). 
Principal component analysis has been used to compare ordination patterns in morphometric and allozymic traits. The input matrix for allozyme analysis consisted of 30 allelic variables (Table 1). It was performed utilizing multilocus genotypic profiles of single individuals. Each individual was characterized for each variable as 1 if homozygous for that allele and as 0.5 if heterozygous. This coding of data allows one to analyse genetic relationships without any a priori assignment of individuals to any group. In addition, the same set of data was employed in a cluster analysis (TRGRPS algorithm by Orloci, 1976) to establish hierarchical relationships among genotypes.

The morphometric matrix for the principal component analysis was based on individual morphometric profiles, consisting of 12 variables (Table 2). Size has been removed according to Jolicoeur and Mosimann (1960). This method assumes that the first component represents overall size, since all characters are positively and similarly correlated with it. So the remaining principal components may be considered as size-independent shape descriptors.

\section{RESULTS}

Table 3 shows allele frequencies per locus for each group. Of the 25 loci assayed, 11 (Aph-1, Ca-1, Fum, Idh-2, Ldh, Me, Pt-2, Pt-4, Pt-5, Pt-6, Sod) were found to be monomorphic, with the same allele in both dark and light groups (a locus is considered polymorphic if the most common allele has a frequency lower than 0.99). The remaining 14 loci ( $A p h-2, A o-1, C a-2, C a-3$, Got, Lap, Mdh-1, Mpi, Pep, Pgm, Phi, Pt-1, Pt-3, Xdh) showed variation at least in one of the two groups.

Some loci show alleles typical of either light or dark crayfishes. The Pgm locus shows 3 alleles, one of which is present in the light crayfishes onlj. The Aph-2 locus shows 3 alleles too, but one is peculiar of the "darks", one of the "lights" and one is shared by the two phenotypes. The Got, Mpi, Pep, and Xdh loci present the same alleles in both groups but with widely different frequencies. Namely, heterozygotes at the Xdh locus were found only in the "dark " sample.

The degree of variability is similar in both groups; expected heterozygosity $(\mathrm{He})$ is 0.125 and 0.120 in light and dark group respectively. Observed heterozygosity per individual is reported in Table 1. 
Table 1. Multilocus genotypic profiles of 18 individuals of Procambarus. Variables consist of 30 allele variants at 14 loci. Individuals are characterized for each variable as 1 if homozygous for that allele and as 0.5 if heterozygous. Heterozygosity per individual $(\mathrm{H})$, observed (Ho) and expected ( $\mathrm{He}$ ) average heterozygosities per group are reported below.

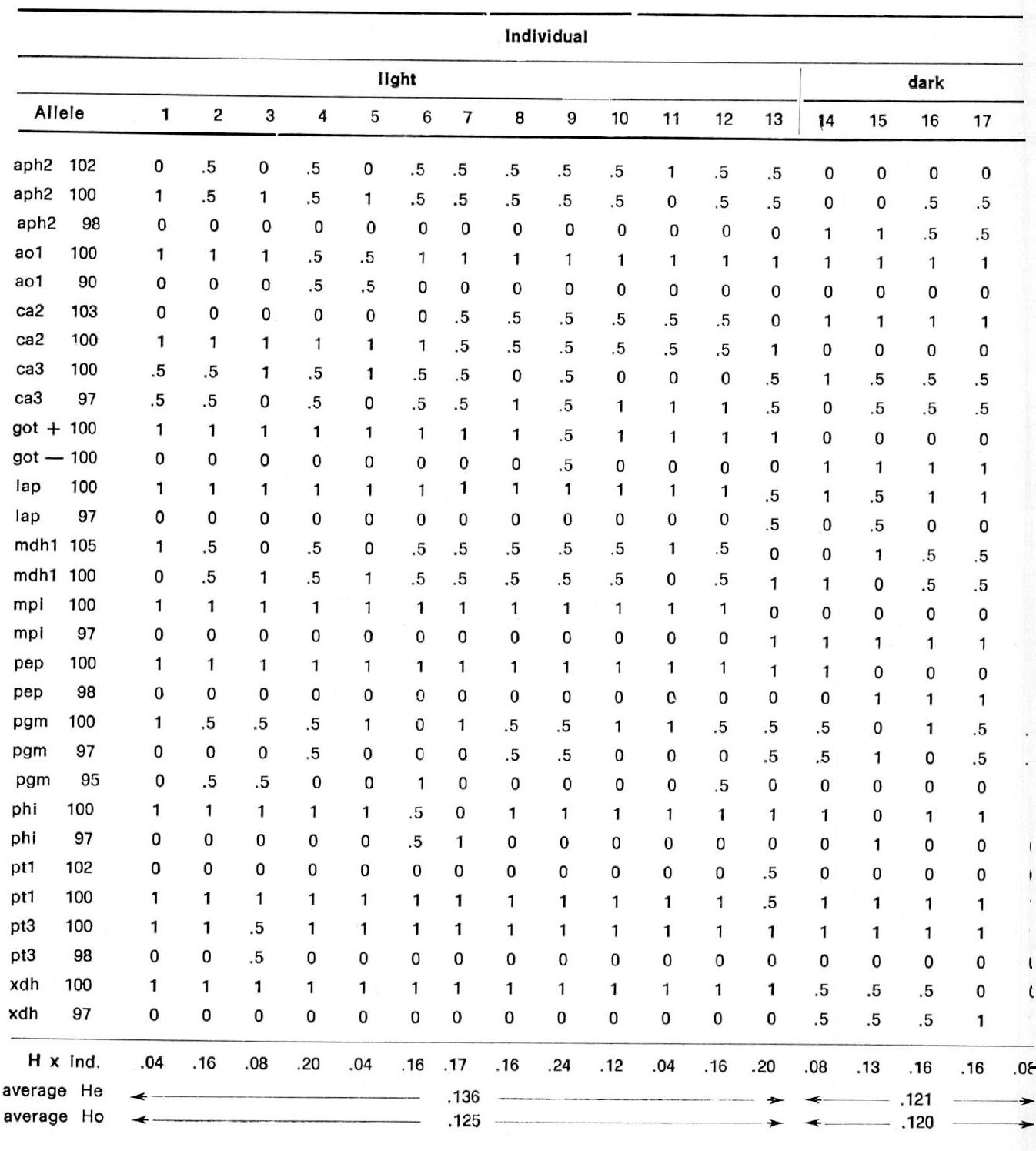




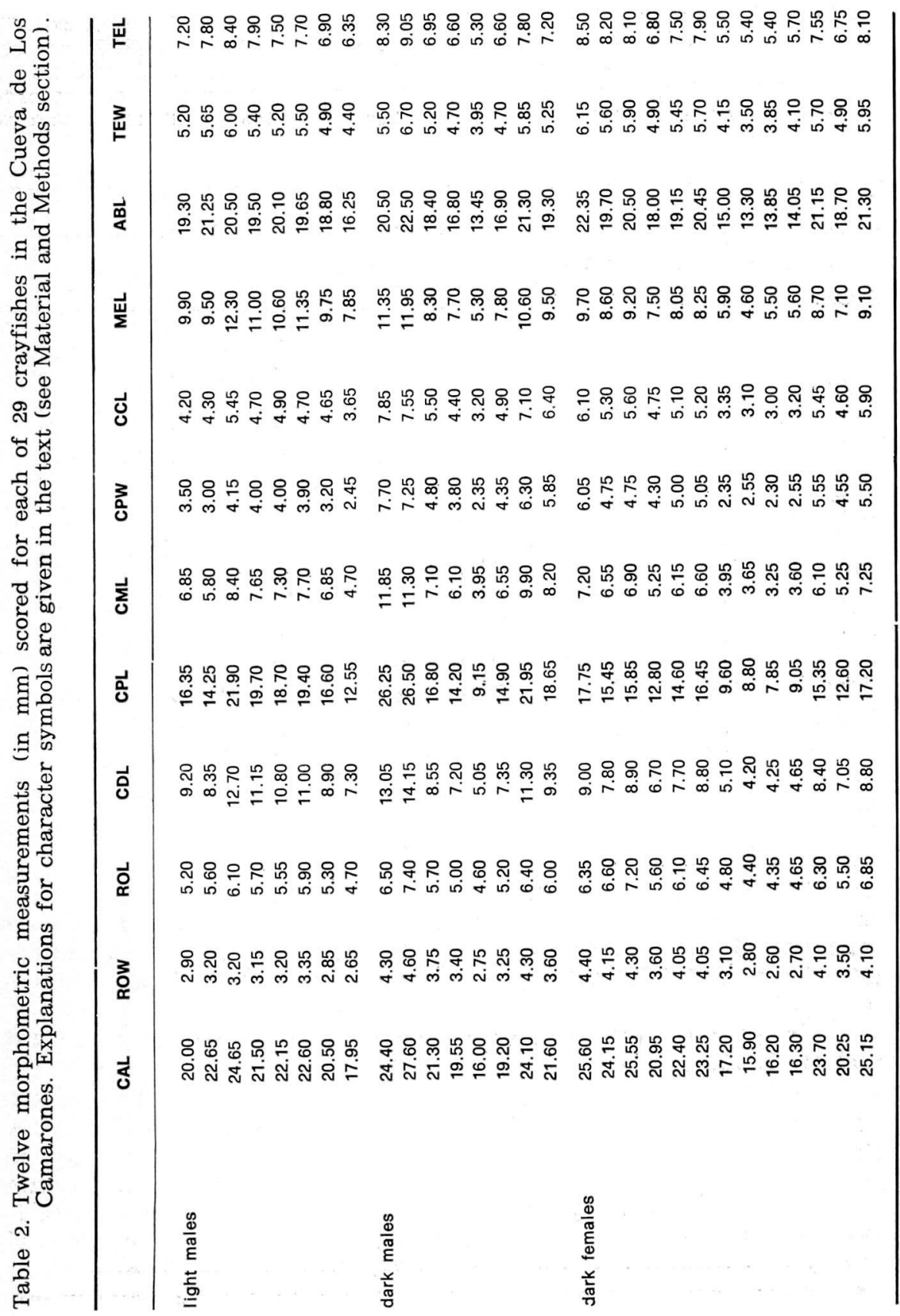


Table 3. Allele frequencies at 25 gene loci coding for enzymes and general proteins in "light " and "dark" phenotypes of Procambarus.

\begin{tabular}{lrrrlrrr}
\hline Locus & Allele & light & dark & Locus & Allele & light & dark \\
\hline Aph1 & 100 & 1.000 & 1.000 & Me & 100 & 1.000 & 1.000 \\
Aph2 & 102 & .423 & .000 & Mpi & 100 & .923 & .000 \\
& 100 & .577 & .200 & & 97 & .077 & 1.000 \\
& 98 & .000 & .800 & Pep & 100 & 1.000 & .200 \\
A01 & 100 & 923 & 1.000 & & 98 & .000 & .800 \\
& 90 & .077 & .000 & Pgm & 100 & .654 & .500 \\
Ca1 & 100 & 1.000 & 1.000 & & 97 & .154 & .500 \\
Ca2 & 103 & .231 & 1.000 & & 95 & .192 & .000 \\
& 100 & .769 & .000 & Phi & 100 & .885 & .800 \\
Ca3 & 100 & .423 & .600 & & 97 & .115 & .200 \\
& 97 & .577 & .400 & Pt1 & 102 & .038 & .000 \\
Fum & 100 & 1.000 & 1.000 & Pt2 & 100 & .962 & 1.000 \\
Got & 100 & .958 & .000 & Pt3 & 100 & .962 & 1.000 \\
& -100 & .042 & 1.000 & & 98 & .038 & .000 \\
Idh2 & 100 & 1.000 & 1.000 & Pt4 & 100 & 1.000 & 1.000 \\
Lap & 100 & .962 & .900 & Pt5 & 100 & 1.000 & 1.000 \\
Ldh & 97 & .038 & .100 & Pt6 & 100 & 1.000 & 1.000 \\
Mdh1 & 100 & 1.000 & 1.000 & Sod & 100 & 1.000 & 1.000 \\
& 105 & .462 & .400 & Xdh & 100 & 1.000 & .300 \\
& 100 & .538 & .600 & & 97 & .000 & .700 \\
\hline & & & & & & & \\
\hline
\end{tabular}

Table 4 provides estimates of $F_{s t}$ for each polymorphic locus across two groups examined. On average, the $F_{s t}$ values are large enough and statistically highly significant (heterogeneity chi-square significant at $\mathrm{P}<0.001$ ), they range from 0.003 to 0.820 with an average of 0.321 .

The genetic distance value between the two groups sampled is 0.208.

Principal component analysis performed on morphometric data reveals that the variables responsible of the differentiation between the light and dark crayfishes are chiefly those reflecting the shape of the rostrum and chela. All 12 characters load positively on component I (PC I) and contribute similarly, thus PC I is very likely size related (Table 5). Component II (PC II) is highly correlated with ROW (negative correlation), MEL and CDL, and accounts for discrimination between light and dark phenotypes. Component III (PC III) is correlated with 
Table 4. F-statistic analysis from data on "light» and "dark " Procambarus subpopulations.

\begin{tabular}{lrrrrr}
\hline Locus & $\begin{array}{c}F \\
\text { light }\end{array}$ & $\begin{array}{c}F \\
\text { dark }\end{array}$ & \multicolumn{1}{l}{ Fis } & Fit & Fst \\
\hline Aph2 & -.418 & -.250 & -.371 & .037 & $.304 \cdots$ \\
Ao1 & -.084 & .000 & -.061 & -.059 & .023 \\
Ca2 & -.301 & .000 & -.218 & .324 & $.480 \cdots$ \\
Ca3 & -.102 & .667 & -.259 & -.225 & .025 \\
Got & -.037 & .000 & -.030 & .815 & $.820 \cdots$ \\
Lap & -.040 & -.111 & -.060 & -.065 & .015 \\
Mdh1 & -.237 & -.167 & -.125 & -.124 & .003 \\
Mpi & 1.000 & .000 & .765 & 1.000 & $.738 \cdots$ \\
Pep & .000 & 1.000 & .278 & 1.000 & $.743 \cdots$ \\
Pgm & -.051 & -.200 & -.092 & -.019 & .066 \\
Phi & .622 & 1.000 & .727 & .767 & .012 \\
Xdh & .000 & -.429 & -.119 & .468 & $.628 \cdots$ \\
Average & & & & & \\
12 loci & .029 & .126 & .036 & .324 & .321 \\
\hline
\end{tabular}

*** $\mathrm{P}$ « 0.001

Table 5. Variable loadings for the principal components for individual mor. phometric analysis in "light" and "dark" Procambarus.

\begin{tabular}{lrrr}
\hline Variable & PC I & PC II & PC III \\
\hline CAL & 0.30 & -0.15 & -0.25 \\
ROW & 0.26 & -0.53 & 0.13 \\
ROL & 0.29 & -0.29 & -0.14 \\
CDL & 0.28 & 0.40 & 0.05 \\
CPL & 0.29 & 0.31 & 0.23 \\
CML & 0.29 & 0.24 & 0.37 \\
CPW & 0.28 & -0.26 & 0.44 \\
CCL & 0.29 & -0.10 & 0.39 \\
MEL & 0.27 & 0.45 & -0.17 \\
ABL & 0.29 & -0.03 & -0.35 \\
TEW & 0.30 & -0.07 & -0.34 \\
TEL & 0.30 & 0.00 & -0.30 \\
\hline
\end{tabular}

CPW, CCL, CML, ABL and TEW, and reveals mainly shape differentiation between dark males and females (for character symbols see section Material and Methods). 
Table 6. Heterozygosity values $(\mathrm{He})$ in freshwater crayfish species.

\begin{tabular}{|c|c|c|c|}
\hline & $\begin{array}{c}\text { number } \\
\text { of Ioci }\end{array}$ & $\mathrm{He}$ & Reference \\
\hline \multicolumn{4}{|l|}{ Procambarus } \\
\hline "light" & 25 & .125 & present paper \\
\hline " dark" & 25 & .120 & present paper \\
\hline acutus & 19 & .025 & Brown, 1981 \\
\hline hirsutus & 19 & .031 & Brown, 1981 \\
\hline pubescens & 19 & .015 & Brown, 1981 \\
\hline raneyi & 19 & .000 & Brown, 1981 \\
\hline troglodytes & 19 & .012 & Brown, 1981 \\
\hline clarkii & 15 & .021 & Attard \& Pasteur, 1984 \\
\hline \multicolumn{4}{|l|}{ Orconectes } \\
\hline immunis & 18 & .043 & Nemeth \& Tracey, 1979 \\
\hline propinquus & 22 & .063 & Nemeth \& Tracey, 1979 \\
\hline virilis & 17 & .032 & Nemeth \& Tracey, 1979 \\
\hline limosus & 15 & .004 & Attard \& Pasteur, 1984 \\
\hline \multicolumn{4}{|l|}{ Cambarus } \\
\hline bartonii & 17 & .087 & Nemeth \& Tracey, 1979 \\
\hline latimanus & 19 & .013 & Brown, 1981 \\
\hline latimanus & 15 & .076 & Nemeth \& Tracey, 1979 \\
\hline robustus & 17 & .044 & Nemeth \& Tracey, 1979 \\
\hline \multicolumn{4}{|l|}{ Astacus } \\
\hline astacus & 15 & .052 & Attard \& Pasteur, 1984 \\
\hline leptodactylus & 15 & .012 & Attard \& Pasteur, 1984 \\
\hline \multicolumn{4}{|l|}{ Austropotamobius } \\
\hline pallipes & 15 & .028 & Attard \& Pasteur, 1984 \\
\hline
\end{tabular}

\section{DISCUSSION}

It has been showed that environmental factors can have a large effect on pigmentation. In particular, Maguire (1961), studying a cave population of another crayfish species, Procambarus simulans simulans, found a situation analogous to that reported in this paper; crayfish collected progressively upstream, nearer to the entrance, were progressively more deeply pigmented. In this case, according to Maguire, the differences in pigmentation chiefly depend on nutritional factors, in relation to carotenoid availability. Although it is lifelike, this explanation cannot fit well to situation found in the Cueva de Los Camarones, because of the high degree of genetic differentiation between the two forms, correlated with their morphological divergence. 
Results of this study showed that the "light " phenotypes of Procambarus inhabiting the Cueva de Los Camarones diverge genetically at a considerable extent from the "dark " ones, with an average $F$ st values of 0.321 and a Nei's D equal to 0.208 . The relatively high genetic distance found between the two forms of Procambarus in Cueva de Los Camarones may bring into question their taxonomic status. D value between "darks" and "lights" falls into the range of genetic distances (Nei's D from 0.111 to 0.382 ) reported by Brown (1981) for five Procambarus species from the Savannah River Plant (South Carolina). In addition, there is clear evidence that Nei's $D$ and degree of reproductive isolation are correlated in cave populations. Data from Dolichopoda cave crickets, Speonomus Bathysciinae beetles and Troglocaris cave shrimps indicate that populations differing by Nei's D greater than 0.20 are reproductively isolated by postmating barriers (Allegrucci et al., 1981, 1982; Cobolli Sbordoni et al., 1983, 1987; Delay et al., 1980; Sbordoni, 1982; Sbordoni et al., 1987). Furthermore by comparing our data with those reported for Astyanax fasciatus (= A.mexicanus; Avise and Selander, 1972) it should be noted that the level of genetic differentiation found between light and dark Procambarus is three times higher than that calculated between Chica cave population and the nearby surface population (Nei's D = 0.07). On the other hand, genetic distances between surface and pure cave dwelling populations of Astyanax, namely A.hubbsi and A.antrobius (average Nei's D equal to 0.151 and 0.206 respectively), are similar to values between the two Procambarus phenotypes.

Principal component analysis, performed on individual allozymic multilocus profiles, confirmed differences between the light and dark crayfishes and suggests that the two forms belong to distinct gene pools (Fig. 2). Genotypes rather than allele frequencies have been considered in ordination analysis. This method appears to be especially advisable in studying relationships among sympatric species and to detect hybridization or possible introgressive individuals. Evidence of hybridization between the two groups is not supplied by allozymes, and data from such a small sample cannot provide positive evidence of introgression.

However, the dendrogram drawn up on the basis of TRGRPS clustering of genotypes reveals some heterogeneity within both "light" and "dark" groups (Fig. 3). On the other hand, heterozygosity values determined for these crayfish species are higher in comparison to reported values for decapods, and in particular for other Procambarus species (Table 6; Attard and Pasteur, 1984; Brown, 1981; Hedgecock et al., 1982; Nelson and 


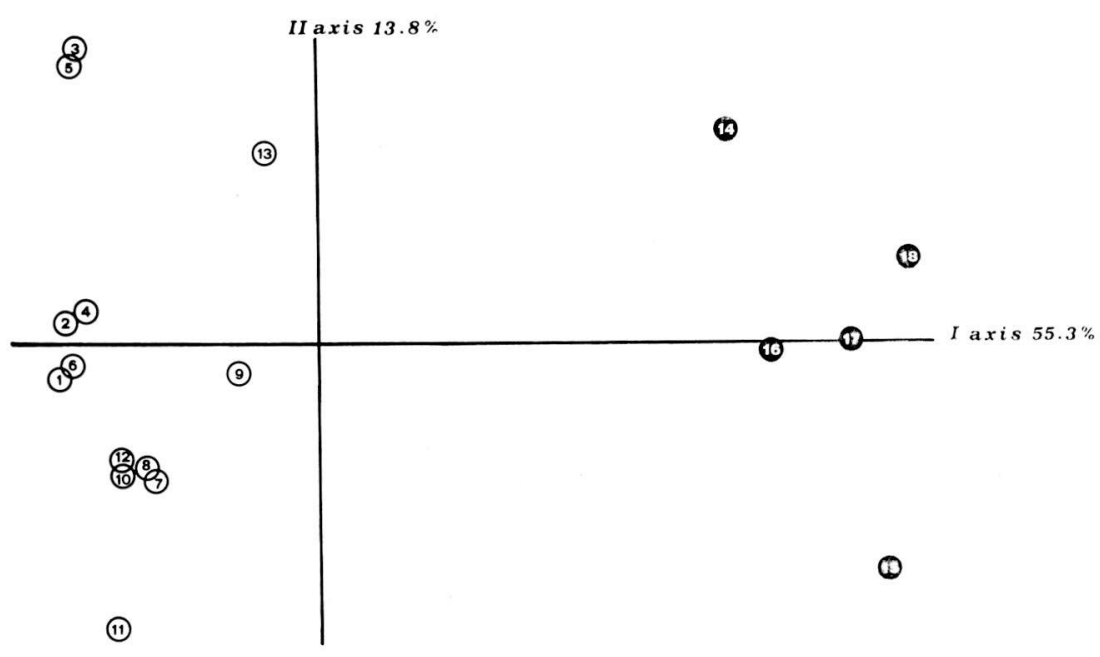

Fig. 2 - Results of the principal component analysis performed on allozymic multilocus profiles of 18 individuals from the Cueva de Los Camarones. Open circles represent "light" individuals; closed circles are "dark " individuals.

Hedgecock, 1980; Nemeth and Tracey, 1979). Sympatric condition of two species in the Cueva de Los Camarones represents a good opportunity for possible occurrence of genic introgression, especially between species of relatively recent origin as the Procambarus "light" and "dark" might be. Thus, some level of introgression could account for the high degree of heterozygosity observed in these species. Actually, heterozygosity values calculated for individual support this hypothesis. Some individuals (n.rs 9, 13 " light "; 16, 17 "dark") show heterozygous condition at about 16-20 per cent of assayed loci, displaying alleles shared by the other species (Table 1 and Fig. 2).

Individual morphometric profiles studied through principal component analysis also show a clear discrimination of the "light" species mainly determined by the shape of the rostrum and chela (Fig. 4). Thus, there is a correlation between the degree of pigmentation and some morphological characters.

The existence of discontinuous variation both in morphometric and allozymic characters presumably reflects a history of 


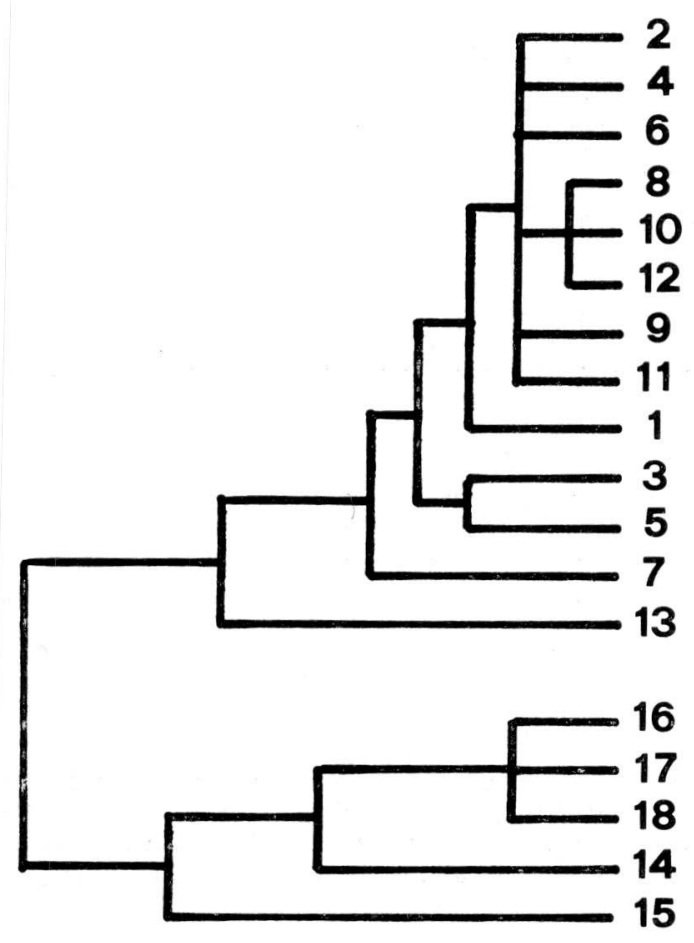

Fig. 3 - Hierarchical relationships among genotypes investigated by TRGRPS algorithm of cluster analysis.

allopatric divergence. It could be supposed that the two crayfish populations have become isolated because of shifting in patterns of drainage or lack of connection between the cave and surface. A subsequent interconnession could have allowed the secondary contact of the two species in the same cave. However, alternative hypothesis such as clinal speciation or differentiation by area effect cannot be ruled out in the present status of research.

Further research in progress is aimed to investigate whether introgression really exists and whether patterns of microgeographic variation within the "light " and "dark" species are detectable both at structural gene loci and in morphometric characters. Moreover, taxonomic treatment of these species by identification of diagnostic morphological characters will be undertook. 


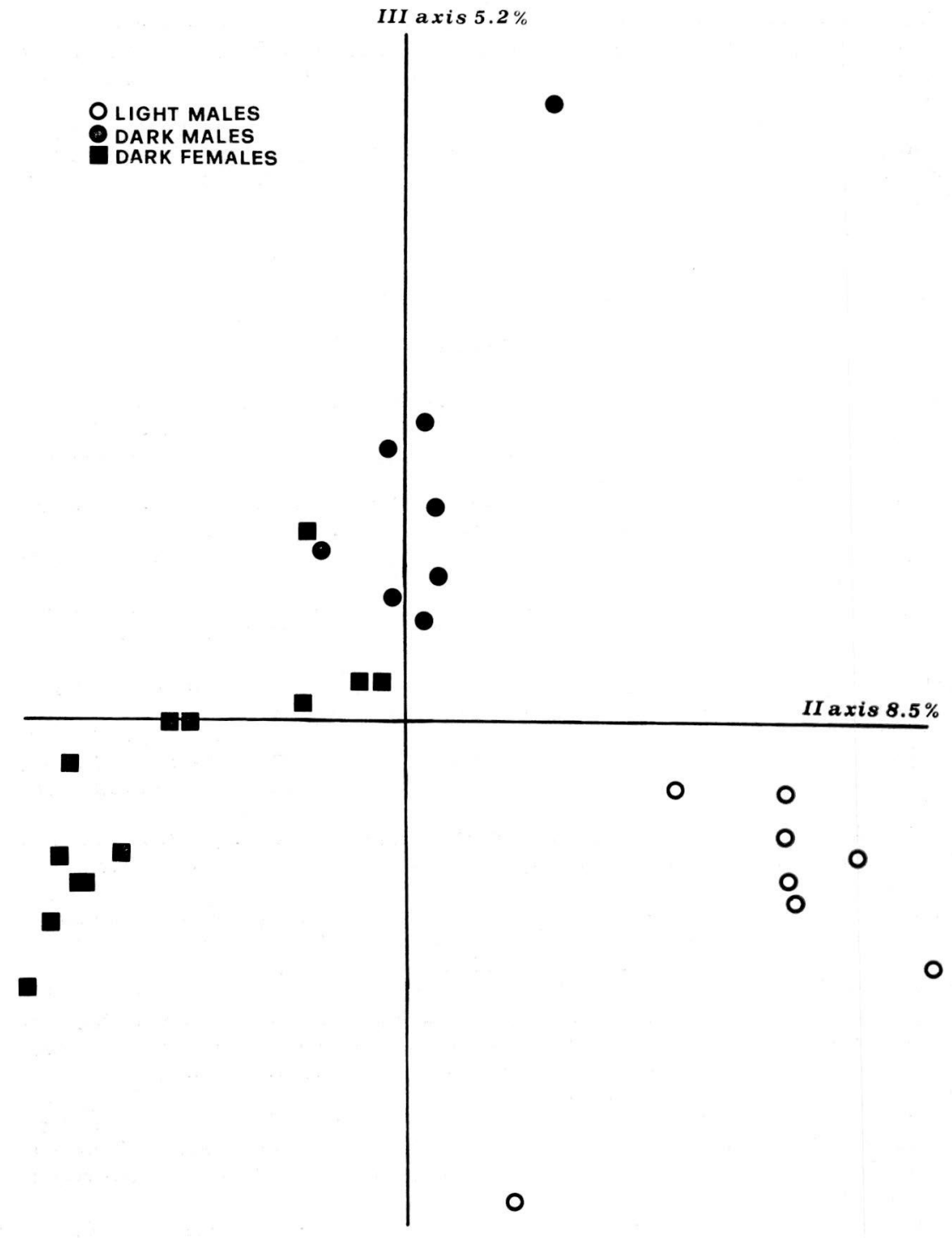

Fig. 4 - Results of the principal component analysis performed on individual morphometric profiles of crayfishes. "Light" samples (open circles) are only males. "Dark" individuals are both males (closed circles) and females (closed squares). First principal component appeared size-related, thus it was removed. 


\section{ACKNOWLEDGEMENTS}

These investigations were supported by grants from Accademia Nazionale dei Lincei, Italian National Research Council (CNR) and Ministry of Education (MPI) to Valerio Sbordoni. We thank Professor G. Montalenti for his continuous stimulus to these researches.

We are grateful to G. Carchini, C. De Monte, R. De Cristofaro, S. Gambari, A. Gobetti, M. Lucarelli and M. Topani for help in collecting Procambarus samples in Mexican caves. Thanks are also due to A. Caccone for help in laboratory.

\section{REFERENCES}

ALLEGRUCCI, G., A. CACCONE, D. CESARONI, M. COBOLLI SBORDONI, E. DE MATTHAEIS and V. SBORDONI. 1981. Prime ricerche sulla genetica di popolazioni naturali del gamberetto cavernicolo Troglocaris anophthalmus. Bool. Zool. 48 (suppl.): 12.

ALLEGRUCCI, G., A. CACCONE, D. CESARONI, M. COBOLLI SBORDONI, E. DE MATTHAEIS and V. SBORDONI. 1982. Natural and experimental interspecific hybridization between populations of Dolichopoda cave crickets. Experientia 38: 96-98.

ATTARD, J. and N. PASTEUR. 1984. Variabilité et différenciation génétique chez cinq espèces d'écrevisses Astacidae. Biochem. Syst. Ecol. 12: $109-117$.

AVISE, J.C. and R.K. SELANDER. 1972. Evolutionary genetics of cavedwelling fishes of the genus Astyanax. Evolution 26: 1-19.

AYALA, F.J., J.R. POWELL, M.L. TRACEY, C.A. MOURAO and S. PEREZ-SALAS. 1972. Enzyme variability in the Drosophila willistoni group. IV. Genetic variation in natural populations of Drosophila willistoni. Genetics 70: 113-130.

BROWN, K. 1981. Low genetic variability and high similarities in the crayfish genera Cambarus and Procambarus. Am. Midl. Nat. 105: 225-232.

CIRCOLO SPELEOLOGICO ROMANO (ed.). 1986. Le spedizioni speleologiche "Malpaso '81" e "Malpaso '84" in Chiapas (Mexico). Notiziario del Circolo Speleologico Romano, n.s. 1. 1-160.

COBOLLI SBORDONI, M., B. DELAY, E. DE MATTHAEIS and V. SBORDONI. 1983. Divergenza genetica e barriere al flusso genico tra popolazioni cavernicole di Speonomus delarouzeei (Coleoptera, Catopidae). Atti XII Congr. Naz. Ital. Entomol., Roma, 2: 247-252.

COBOLLI SBORDONI, M., M. MATTOCCIA, G. LA ROSA, E. DE MATTHAEIS and V. SBORDONI. 1987. Secondary sympatric occurrence of sibling species of subterranean shrimps in the Karst. Founding Congress of European Society for Evolutionary Biology, Basel, Switzerland, 26-30 August 1987, Abstract.

CULVER, D.C. 1982. Cave life. Harvard University Press, Cambridge, Massachusetts and London, England.

DELAY, B., V. SBORDONI, M. COBOLLI SBORDONI, and E. DE MATTHAEIS. 1980. Divergences génétiques entre les populations de Speonomus delarouzeei du Massif du Canigou (Coleoptera, Bathysciinae). Mém. Biospéol. 7: 235-247.

GAMBARI, S. and M. TOPANI. 1986. Descrizioni delle cavità esplorate. In: Le spedizioni speleologiche "Malpaso '81" e "Malpaso '84" in Chiapas (Mexico). Notiziario del Circolo Speleologico Romano, n.s., 1: 41-72. 
HARRIS, H., and D.A. HOPKINSON. 1976. Handbook of enzyme electrophoresis in human genetics. North-Holland Publ. Comp., Amsterdam.

HEDGECOCK, D., M.L. TRACEY and K. NELSON. 1982. Genetics, p. 283403. In: L.G. Abele (ed.), The Biology of Crustacea, vol. 2. Academic Press Inc., New York.

JOLICOEUR, P., and J.E. MOSIMANN. 1960. Size and shape variation in the painted turtle. A principal component analysis. Growth 24: 339-354.

MAGUIRE, B. Jr. 1961. Regressive evolution in cave animals and its mechanism. Tex. J. Sci. 13: 363-370.

MITCHELL, R.W., W.H. RUSSELL and W.R. ELLIOTT. 1977. Mexican eyeless characin fishes, genus Astyanax: environment, distribution, and evolution. Spec. Publ. Museum Texas Tech. Univ. 12: 1-89.

NEI, M. 1972. Genetic distance between populations. Am. Nat. 106: 283-292.

NELSON, K. and D. HEDGECOCK. 1980. Enzyme polymorphism and adaptive strategy in the Decapod crustacea. Am. Nat. 116: 238-280.

NEMETH, S.T. and L.T. TRACEY. 1979. Allozyme variability and relatedness in six crayfish species. J. Hered. 70: 37-43.

ORLOCI, L. 1976. TRGRPS. An interactive algorithm for group recognition with an example from Spartinetea. Vegetatio 32: 117-120.

REDDELL, J.R. 1981. A review of the cavernicole fauna of Mexico, Guatemala and Belize. Bull. Texas Memor. Museum Univ. Texas Austin 27: 1-327.

SBORDONI, V. 1982. Advances in speciation of cave animals, pp. 219-240. In: C. Barigozzi (ed.), Mechanisms of speciation, Alan R. Liss Inc., New York.

SBORDONI, V. and R. ARGANO. 1972. Introduction; caves studied during the 1st mission to Mexico (1969). In: Subterranean fauna of Mexico, part 1, Quaderni Acc. Naz. Lincei 171 (1): 5-21.

SBORDONI, V., R. ARGANO and. A. ZULLINI. 1973. Biological investigations on the caves of Chiapas (Mexico) and adjacent countries: introduction. In: Subterranean fauna of Mexico, part 2, Quaderni Acc. Naz. Lincei 171 (2): 5-45.

SBORDONI, V., R. ARGANO, V. VOMERO and. A. ZULLINI. 1977. Ricerche sulla fauna cavernicola del Chiapas (Messico) e delle regioni limitrofe: grotte esplorate nel 1973 e nel 1975. Criteri per una classificazione biospeleologica delle grotte. In: Subterranean fauna of Mexico, part 3, Quaderni Acc. Naz. Lincei 171 (3): 5-74.

SBORDONI, V., R. ARGANO and V. VOMERO. 1986. Relazione biologica sulle spedizioni "Malpaso " 1981-82 e 1984. In: Le spedizioni speleologiche "Malpaso '81" e "Malpaso '84" in Chiapas (Mexico). Notiziario del Circolo Speleologico Romano, n.s., 1: 73-88.

SBORDONI, V., G. ALLEGRUCCI, A. CACCONE, G. CARCHINI and D. CESARONI. 1987. Microevolutionary studies in Dolichopodinae cave crickets. pp. 514-540. In: B. Baccetti (ed.), Evolutionary Biology of Orthopteroid Insects. Ellis Horwood Ltd., Chichester, England.

WILKENS, H. 1972. Zur phylogenetischen Rückbildung des Auges Cavernicoler: Untersuchungen an Anoptichthys jordani $(=$ Astyanax mexicanus), Characidae, Pisces. Ann. Spéléol. 31: 137-148.

WILKENS, H. 1985. The evolution of polygenic systems, studied on epigean and cave populations of Astyanax fasciatus (Characidae, Pisces). NSS Bulletin 47: 101-108.

WORKMAN, P.L. and J.D. NISWANDER. 1970. Population studies on southwestern Indian tribes. II. Local genetic differentiation in the Papago. Am. J. Hum. Genet. 22: 24-49.

WRIGHT, S. 1965. The interpretation of population structure by F-statistics, with special regard to systems of mating. Evolution 19: 395-420. 